\title{
Activities of the Korean Red Cross Blood Programme (1990-1993)
}

\author{
Young Chul Oh, M.D. \\ Korean Red Cross Blood Products Research Inst.
}

\section{Introduction}

In Korea, the blood programme was started by the Korean Red Cross in 1958. The Korean government has entrusted the Korean Red Cross with the whole national blood programme since July, 1981. Presently, there are 15 Red Cross Blood Centers and 123 college and general hospital blood banks in Korea.

This is a summary of the activities of the Korean Red Cross with the blood programme in Korea during the recent 4 years.

\section{Donor Distribution by Province}

The annual numbers of blood collections by 15 regional Red Cross Blood Centers are shown in table 1. The total number of annual blood donation has about 1.1 million in 1990 to about 1.5 million in 1993. Blood Centers in Seoul, capital of Korea, occupy about $40 \%$ of the collection by Korean Red Cross Blood Centers. The numbers in Table 1 say that the blood collection in 1993 shows a $40 \%$ increase over 1990 .

\section{Annual Number of Blood Collections}

The total annual collection of blood by Red Cross Blood Centers and Hospitals are shown in Table 2 . The collection by Red Cross is about $97.5 \%$, otherwise hospitals blood centers are $2.5 \%$ in 1993.

\section{Age Distribution of Blood Donors}

The young in their teenage and twenties consist of $90 \%$ blood donors in Korea. The $22.7 \%$ of

Table 1. Donor Distribution by Province (unit)

\begin{tabular}{l|r|r|r|r}
\hline \multicolumn{1}{c|}{ Area/Yr } & \multicolumn{1}{c|}{1990} & \multicolumn{1}{c|}{1991} & \multicolumn{1}{c}{1992} & \multicolumn{1}{c}{1993} \\
\hline No. Donor & $1,100,541$ & $1,161,314$ & $1,305,766$ & $1,540,016$ \\
Seoul & 447,194 & 439,420 & 497,719 & 613,968 \\
Pusan & 110,306 & 100,238 & 101,542 & 117,349 \\
Incheon & 49,657 & 56,858 & 66,493 & 86,169 \\
Kyunggi & 44,004 & 49,237 & 56,808 & 71,101 \\
Kangwon & 60,935 & 67,157 & 69,010 & 76,863 \\
Choongbuk & 34,410 & 41,619 & 49,909 & 58,904 \\
Daejeon & 76,164 & 75,414 & 89,786 & 96,863 \\
Jeonbuk & 44,664 & 50,545 & 50,971 & 62,776 \\
Kwanju & 57,341 & 77,220 & 79,410 & 90,159 \\
Daegu & 126,070 & 131,052 & 152,908 & 155,670 \\
Kyungnam & 41,838 & 47,773 & 56,055 & 63,518 \\
Ulsan & - & 13,841 & 23,785 & 34,696 \\
Jeju & 7,958 & 10,940 & 11,370 & 11,980 \\
\hline
\end{tabular}

Table 2. Annul Number of Blood Collections (unit)

\begin{tabular}{c|c|c|c|c|c}
\hline \multirow{2}{*}{ Year } & \multirow{2}{*}{ Number } & \multicolumn{2}{l|}{ Korean Red Cross } & \multicolumn{2}{c}{ Hospital B/C } \\
\cline { 3 - 6 } & & No. & $\%$ & No. & $\%$ \\
\hline 1990 & $1,154,241$ & $1,100,541$ & 95.3 & 53,700 & 4.7 \\
1991 & $1,215,199$ & $1,161,314$ & 95.6 & 53,885 & 4.4 \\
1992 & $1,356,796$ & $1,305,766$ & 96.2 & 51,030 & 3.8 \\
1993 & $1,580,068$ & $1,540,016$ & 97.5 & 40,052 & 2.5 \\
\hline
\end{tabular}


Table 3. Age Distribution of Blood Donors (\%)

\begin{tabular}{c|c|c|c|c|c}
\hline Year/Age & $16-19$ & $20-29$ & $30-39$ & $40<$ & Total \\
\hline 1990 & 28.0 & 59.3 & 10.0 & 2.7 & 100 \\
1991 & 27.3 & 61.2 & 8.8 & 2.7 & 100 \\
1992 & 23.3 & 65.6 & 7.9 & 3.2 & 100 \\
1993 & 22.7 & 67.4 & 7.1 & 2.8 & 100 \\
\hline
\end{tabular}

Table 4. Sex Distribution of Blood Donors

\begin{tabular}{c|c|c|c|c|r}
\hline \multirow{2}{*}{ Year } & \multirow{2}{*}{ Donor No. } & \multicolumn{2}{|c|}{ Male } & \multicolumn{2}{c}{ Female } \\
\cline { 3 - 6 } & & No. & $\%$ & No. & \multicolumn{1}{c}{$\%$} \\
\hline 1990 & $1,154,241$ & $1,046,737$ & 90.7 & 107,504 & 9.3 \\
1991 & $1,215,199$ & $1,091,285$ & 89.8 & 123,914 & 10.2 \\
1992 & $1,356,796$ & $1,234,488$ & 91.0 & 122,308 & 9.0 \\
1993 & $1,580,068$ & $1,448,385$ & 91.7 & 131,683 & 8.3 \\
\hline
\end{tabular}

donors are teenagers and $67.4 \%$ of donors are in their twenties in 1993.

\section{Sex Distribution of Blood Donors}

The donor distribution by sex is shown in Table 4 .

The male donors increased very much each year, but female donors did not. The $91.7 \%$ of blood donors in Korea are male, and $8.3 \%$ of blood donors are female in 1993. Because most of female are afraid of blood donation, they are less than male donors.

\section{Status of Blood Component Transfusion}

Not only the total number of blood transfusion has been increasing in the country, but also the proportion of the blood component therapy also increasing markedly since its introduction in the mid80's. Blood components transfusions accunted for $95.0 \%$ of all transfusion in 1993.

$54.2 \%$ of component the transfusion was PRC, $24.5 \%$ was plasma, and $20.7 \%$ was platelet last year. We can see the increase of component transfusion, otherwise markedly the decrease of whole blood transfusion.

\section{Distribution of ABO, Rh Blood Group}

Blood types of the donors were determined using anti-A and anti-B antisera supplied by the Green Cross Company Limited, Korea. Among donors in Korea last year, A, B, O and AB groups accounted for $34.3 \%, 27.2 \%, 27.1 \%$ and $11.4 \%$ respectively. $\mathrm{Rh}(\mathrm{D})$ negative donors were only $0.3 \%$ of the whole

Table 5. Distribution by supply

\begin{tabular}{c|c|c|c}
\hline Year & Donors & Whole Blood (\%) & Components (\%) \\
\hline 1990 & $1,154,241$ & 19.5 & 80.5 \\
1991 & $1,215,199$ & 9.2 & 90.8 \\
1992 & $1,356,796$ & 6.7 & 93.3 \\
1993 & $1,580,068$ & 5.0 & 95.0 \\
\hline
\end{tabular}

Table 7. Distribution of ABO, Rh Blood Group (\%)

\begin{tabular}{c|c|c|c|c|c|c}
\hline Year & Total & A & B & O & AB & Rho (D) Negative \\
\hline 1990 & $1,154,241$ & 34.2 & 27.0 & 27.4 & 11.4 & 0.3 \\
1991 & $1,215,199$ & 34.2 & 27.1 & 27.4 & 11.4 & 0.3 \\
1992 & $1,356,796$ & 34.3 & 27.1 & 27.3 & 11.3 & 0.3 \\
1993 & $1,580,068$ & 34.3 & 27.2 & 27.1 & 11.4 & 0.3 \\
\hline
\end{tabular}

Table 6. Distribution by blood components

\begin{tabular}{c|c|c|c|c|c}
\hline Year & $\begin{array}{c}\text { PRC } \\
(\%)\end{array}$ & $\begin{array}{c}\text { Leucocyte } \\
(\%)\end{array}$ & $\begin{array}{c}\text { Platelet } \\
(\%)\end{array}$ & $\begin{array}{c}\text { Plasma } \\
(\%)\end{array}$ & $\begin{array}{c}\text { Cryo } \\
(\%)\end{array}$ \\
\hline 1990 & 57.6 & 0.4 & 17.8 & 23.3 & 1.0 \\
1991 & 61.0 & 0.3 & 15.1 & 23.8 & 0.4 \\
1992 & 57.7 & 0.2 & 17.5 & 24.3 & 0.3 \\
1993 & 54.2 & 0.1 & 20.7 & 24.5 & 0.3 \\
\hline
\end{tabular}

Table 8. Sero-positive Rate of HBsAg and Syphilis Test in Blood Donors (\%)

\begin{tabular}{c|c|c|c|c|c}
\hline \multirow{2}{*}{ Year } & \multirow{2}{*}{ Tested No. } & \multicolumn{2}{|c|}{ HBsAg } & \multicolumn{2}{c}{ VDRL } \\
\cline { 3 - 6 } & & No. & $\%$ & No. & $\%$ \\
\hline 1990 & $1,100,541$ & 64,774 & 5.89 & 1,277 & 0.12 \\
1991 & $1,161,314$ & 64,137 & 5.52 & 1,433 & 0.12 \\
1992 & $1,305,766$ & 67,197 & 5.15 & 1,640 & 0.13 \\
1993 & $1,540,016$ & 69,287 & 4.50 & 2,010 & 0.13 \\
\hline
\end{tabular}


Table 9. Sero-Positive Rate of Anti-HIV in Blood Donors (\%)

\begin{tabular}{|c|c|c|c|c|c|c|c|}
\hline \multirow{2}{*}{ Year } & \multirow{2}{*}{ Tested No. } & \multicolumn{2}{|c|}{ EIA Initially Reac. } & \multicolumn{2}{|c|}{ EIA Repeatedly Reac. } & \multicolumn{2}{|c|}{ Confirmed Positive (W/B) } \\
\hline & & No. & $\%$ & No. & $\%$ & No. & $\%$ \\
\hline 1990 & 458,989 & 870 & 0.19 & 308 & 0.07 & 1 & 0.0002 \\
\hline 1991 & $1,161,314$ & 2,986 & 0.26 & 1,687 & 0.15 & 3 & 0.0003 \\
\hline 1992 & $1,305,766$ & 3,559 & 0.27 & 1,752 & 0.13 & 18 & 0.0014 \\
\hline 1993 & $1,540,016$ & 2,739 & 0.18 & 1,171 & 0.76 & 14 & 0.0009 \\
\hline
\end{tabular}

${ }^{*}$ HIV has been screened by a EIA since July, 1987

Table 10. The Sero-Positive Rate of Anti-HCV of Blood Donors (\%)

\begin{tabular}{c|c|c|c}
\hline \multirow{2}{*}{ Year } & \multirow{2}{*}{ Tested Number } & \multicolumn{2}{|c}{ Anti-HCV $(+)$} \\
\cline { 3 - 4 } & & No. & $\%$ \\
\hline 1990 & - & - & - \\
1991 & 798,086 & 4,578 & 0.57 \\
1992 & $1,305,766$ & 6,855 & 0.52 \\
1993 & $1,540,016$ & 7,421 & 0.48 \\
\hline
\end{tabular}

* HCV has been screened by a EIA since May, 1991
Table 11. Price of Blood Products $(\$)$

\begin{tabular}{l|c|c}
\hline \multirow{2}{*}{\multicolumn{1}{c|}{ Item }} & \multicolumn{2}{|c}{ price of blood unit (\$) } \\
\cline { 2 - 3 } & $320 \mathrm{~m} l$ & $400 \mathrm{~m} l$ \\
\hline Whole Blood & 21 & 26 \\
Packed Red Cell & 21 & 26 \\
Washed Red Cell & 30 & 40 \\
Leukocyte Poor Red Cell & 30 & 40 \\
Leukocyte Concentrate & 30 & 40 \\
Platelet Concentrate & 30 & 40 \\
Fresh Frozen Plasma & 21 & 26 \\
Cryoprecipitate & 11 & 14 \\
\hline
\end{tabular}

blood donors in 1993.

\section{Sero-Positive Rate of HBsAg and Syphilis Test in Blood Donors}

The sero-positive rates of $\mathrm{HBsAg}$ and syphilis test to blood donors are shown in Table 8 . HBsAg was determined with Behring Enzignost-HBsAg micro-EIA Test. The sero-positive rate of HBsAg was $4.50 \%$ and syphilis antibody was determined with VDRL method, syphilis reactive was $0.13 \%$ in 1993.

\section{Sero-Positive Rate of Anti-HIV in Blood Donors}

In Korea, screening of the anti-HIV for blood donor was begun July 1987. The anti-HIV screening was done by EIA using the domestic reagent. In 1993, 2,739 donors reacted at the EIA Initial Test. 1,171 reacted at EIA Repeated Test, and 14 was confirmed HIV positive. When the repeated EIA reactive case in blood center send to the NIH for confirmation with W/B. HIV reactive case is controlled in NIH.

\section{The Sero-Positive Rate of Anti-HCV of Blood Donors}

In Korea, HCV has been screened by EIA since May 1991. The sero-positive rate of anti-HCV of blood donors in 1993 was $0.48 \%$.

\section{Donor Criteria}

Donor criteria is varous by donation type. The interval between whole blood donations is two month and that between component donations is 72 hours. $400 \mathrm{ml}$ whole blood donors should be older than 16 years and be younger than 66 years, and other types of donors can donate their blood one year early. 
Table 12. Price of Blood Products Collected by

Apheresis

\begin{tabular}{l|c}
\hline \multicolumn{1}{c|}{ Item } & price of blood unit (\$) \\
\hline Plasmapheresis & 153 \\
Thrombocytapheresis & 157 \\
Leukapheresis & 236 \\
Combined Apheresis & 236 \\
\hline
\end{tabular}

\section{Screening Test for Blood Donor}

1. $\mathrm{ABO}$ and $\mathrm{Rh}$ blood group

2. Syphilis serological test

3. HBs antigen test

4. HCV antibody test

5. HIV antibody test

6. Biochemical test

1) Serum transaminase (ALT)

2) Total protein

3) Albumin

4) Albumin-globulin ratio

5) Urea nitrogen

6) Cholesterol

\section{Screening Tests for Apheresis Donors}

There are additional tests for apheresis Donors to that of whole blood tests. The additional tests can be red cell count, white cell count, platelet count, hemoglobin level, hematocrit value, mean corpuscular volume and mean corpuscular hemoglobin concentrations.

1. Including the screening list for blood donor

2. Red cell count

3. White cell count

4. Platelet count

5. Hemoglobin level

6. Hematocrit value

7. Mean corpuscular volume

8. Mean corpuscular hemoglobin concentrations

\section{Price of Blood Products}

A $400 \mathrm{ml}$ unit of $\mathrm{WB}, \mathrm{PRC}$ or FFP is $\$ 26$, that of Cryoprecipitate is $\$ 14$, and others are $\$ 40$.

\section{Price of Blood Products Collected by Apheresis}

A unit of plasma collected by apheresis is $\$ 153$. Thrombocyte is $\$ 157$, Leukocyte and Combined Product are $\$ 236$.

\section{Trend of Apheresis Blood Donors}

The collection of blood by Apheresis are 2,785 units in 1993, and 3,264 units until 1994. 4. The Korean Red Cross will focus on the recruitment of apheresis donors in 1994. The Society plans to recruit 50,000 apheresis donors in 1994 . 